ZalǫcZnilf

DOI 10.21697/zk.2020.7.04

\title{
TWARZ I (JEJ) BRAK. O FILMIE LOKATOR ALFREDA HITCHCOCKA
}

IZABELA TOMCZYK-JARZYNA

\author{
Wydział Nauk Humanistycznych UKSW \\ Faculty of Humanities, \\ Cardinal Stefan Wyszyński University in Warsaw \\ izatomczyk@interia.pl \\ ORCID: 0000-0003-3674-1102
}

W legendarnym wywiadzie-rzece François Truffaut określił Lokatora (The Lodger - A Story of the London Fog, 1927) mianem filmu o „wielkiej pomysłowości wizualnej”. Alfred Hitchcock, odpowiadając na tę sugestię francuskiego reżysera, dużą część swojej wypowiedzi poświęcił detalicznemu opowiedzeniu pierwszego kwadransa filmu. Jest to intrygujący passus. Przykład piętnastominutowej sekwencji był dla reżysera $\mathrm{z}$ jednej strony doskonałym pretekstem, aby wyjaśnić, na czym polegała w jego wykonaniu realizacja „pomysłów w formie czysto wizualnej”, z drugiej - Hitchcock wskazał, że dopiero po zamknięciu owych piętnastu minut wprowadził na ekran tytułowego bohatera. Jest jeszcze jednak coś, na co warto zwrócić uwagę. Snując swoją opowieść, reżyser, trochę na zasadzie ciekawostki, zwierzył się swojemu rozmówcy z pomysłu, którego nie zdołał przedstawić $\mathrm{w}$ formie wizualnej. Ciekawostka była dla niego na tyle istotna, że poprosił Truffaut'a o pożyczenie pióra i narysował ujęcie, którego idealna wersja pozostała tylko w jego głowie.

To jest furgonetka gazety - tłumaczył Hitchcock - pokazana od tyłu, przez owalne okna można dostrzec głowy dwóch mężczyzn siedzących z przodu pojazdu, kierowcy i członka ekipy; przez okna widać tylko czubki ich głów, a ponieważ pojazd się trzęsie, wygląda jak twarz z parą oczu, z ruszającymi się źrenicami. Niestety, nie wyszło ${ }^{2}$.

1 F. Truffaut, Hitchcock / Truffaut, współpraca H. Scott, tłum., oprac. i posłowie T. Lubelski, Izabelin 2005, s. 44.

2 Ibidem, s. 45-46. 
Rzeczywiście, w filmie jest krótkie ujęcie próbujące odwzorować pierwotny pomysł. Widać zbliżenie na zaokrąglone okna kabiny samochodu i siedzących w środku mężczyzn, jednak gdy samochód odjeżdża, kamera rejestruje tylko napis na jej tylnych drzwiach: „The Avenger!”, po czym Hitchcock decyduje się na cięcie, by w kolejnym ujęciu filmować już ze środka kabiny. Być może rozstrzygając między jednoznacznością napisu a metaforycznością twarzy, reżyser ostatecznie przychylił się ku temu pierwszemu. Dlaczego? Do czego miało prowadzić widza to ujęcie?
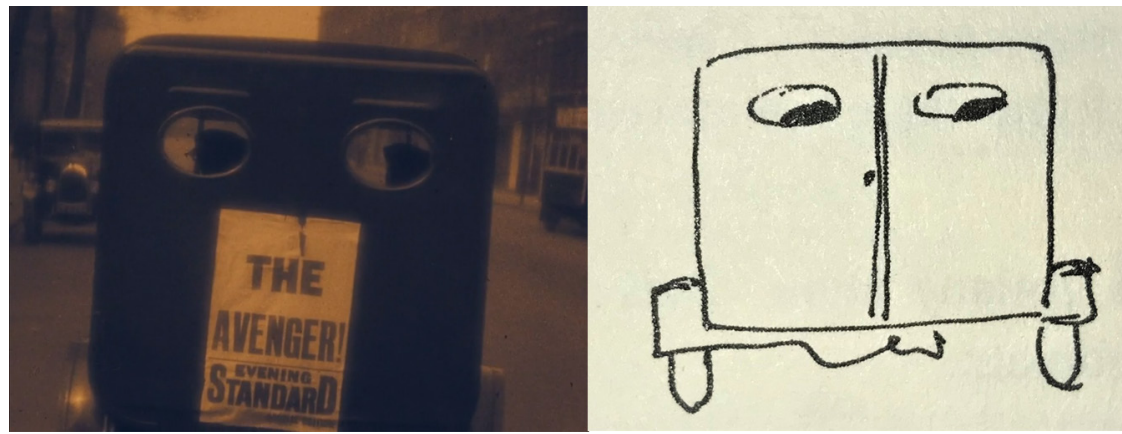

Il. 1 i 2. Rysunek Alfreda Hitchcocka przedstawiajacy furgonetkę-twarz i kadr z filmu Lokator

Wróćmy do początku filmu. Z Tamizy wyłowiono ciało dziewczyny. Są jacyś świadkowie, policja i dziennikarze. Jest informacja o tajemniczym Avengerze, mordercy, która zaczyna krążyć wśród mieszkańców miasta, zaczyna oddziaływać na mieszkańców. Z przekazanej przez telefon historii wydarzenie staje się tekstem spisanym w formie artykułu, skopiowanym w drukarni w tysiącu egzemplarzy i umieszczonym w furgonetce, by rozejść się szerokim echem po Londynie. Kadr przedstawiający opatrzoną plakatem furgonetkę popołudniowej gazety jest definicyjnym, imiennym wskazaniem, że to, co znajduje się w jej wnętrzu, to jest prawdziwy Avenger, to jest jego prawdziwa historia. Chyba nie o to chodziło reżyserowi. „Niestety”, którym komentuje Hitchcock fakt, że ujęcie przepadło, świadczy o tym, że on sam myślał o czymś więcej. Tekst gazetowy to powierzchniowy komunikat roszczący sobie prawo do jednoznacznych rozstrzygnięć. Chęć stworzenia metafory świadczy o tym, że reżyser nie chciał w jednoznaczny sposób opowiadać o rzeczywistości, że Avenger nie był dla niego jednowymiarową 
medialną kreacją. Problem polega na tym, że zastosowana metafora musi być satysfakcjonująca dla twórcy, ale też zrozumiała dla odbiorcy ${ }^{3}$. Podejmując taką, a nie inną decyzję, reżyser musiał uznać, że jego pomysł nie będzie wystarczająco czytelny dla widzów. Inna sprawa, że ostatecznie pomysł antropomorfizowania furgonetki zrealizuje w innym filmie - w Ptakach (The Birds, 1967), tym razem koncentrując się na aspekcie dźwiękowym. Myślę o scenie, w której matka Mitcha, po tym, jak odkryła ciało farmera zadziobanego przez ptaki, ucieka przerażona do samochodu. Hitchcock tak to komentuje:

W poprzedniej scenie pokazaliśmy kobietę w stanie gwałtownej emocji. Ta kobieta wsiadła do furgonetki, powinienem zatem pokazać teraz furgonetkę, która doznaje emocji. Nie tylko obraz [odjeżdżający samochód wznosi tumany kurzu - przyp. I.T.-J.], także dźwięk powinien podtrzymywać tę emocję; toteż dźwięk, który słyszymy, nie jest zwykłym hałasem silnika; to coś w rodzaju krzyku, jaki wydaje z siebie furgonetka ${ }^{4}$.

3 W tym okresie swojej twórczości Hitchcock był pod wpływem zarówno reżyserów niemieckiego ekspresjonizmu filmowego, jak i radzieckiej szkoły montażu (por. P. McGilligan, Alfred Hitchcock. Życie w ciemności i petnym świetle, tłum. J. Matys, A. i A. Nermerowie, I. Stąpor, Warszawa 2005, s. 101). Doskonale znał przemyślenia Lwa Kuleszowa, dla którego kadr, podobnie jak znak w alfabecie chińskim, oznaczał nie rzecz, lecz pojęcie: „W filmie kadr to całe pojęcie i pojęcie to powinno dać się odczytać od początku do końca" (L. Kuleszow, Sztuka filmowa. Moje doświadczenia, red. i wstęp W. Godzic, tłum. zbiorowe, Kraków 1996, s. 50). Z tak pojmowanego kadru-znaku twórca niczym z cegiełek mógł wznieść dowolną konstrukcję.

4 F. Truffaut, op. cit., s. 276. Patrick McGilligan w biografii reżysera wymienia jeszcze jedną scenę, która łączy Lokatora z późniejszą o kilkadziesiąt lat Psychoza (Psycho, 1960); opowiadając o kąpieli Daisy, pisze: „Kiedy Daisy rozkoszuje się pienistą kąpielą, lokator, zasypiający właśnie w swoim mieszkaniu nad schodami, zauważa parę unoszącą się z okna. Podniecony myślą o dziewczynie (publiczność z pewnością myśli, że marzy, aby ją złapać za kark i głaskać po złotych lokach), skrada się na dół i ostrożnie naciska klamkę u drzwi do łazienki. Ta świetna scena wyprzedza o trzydzieści lat kadr z Psychozy, w którym Janet Leigh wchodzi pod prysznic. Do tej chwili publiczność przekonywano, że lokator jest Mścicielem. Gdyby Hitchcock miał wybór, Novello prawdopodobnie otworzyłby drzwi. W 1926 roku musiały pozostać zamknięte”; P. McGilligan, op. cit., s. 106. 
Nieudane ujęcie z Lokatora, z jednej strony niedokonane, a z drugiej pozostające w pewnej potencjalności, w pewnej możliwości zaistnienia, zdradza zasadniczy zamysł dotyczący filmu. Motywem, który porządkuje historię na jej różnych poziomach - wizualnym, emocjonalnym, metaforycznym, konstrukcyjnym - jest twarz. Co więcej - podobnie jak owo ujęcie, które jest niezrealizowane, a jednak w jakiś sposób istniejące, bo możliwy jest do wskazania moment, w którym miało się pojawić - twarz w tym filmie pojawia się w określonym kształcie i rozpływa w bezkształcie, w braku ukonkretnienia.

Rysunek Hitchcocka daje mi pewną swobodę interpretacyjną i pozwala nie traktować twarzy li tyko jako ludzkiego oblicza. Chcę rozumieć twarz jako zestaw elementów decydujących o tożsamości, definiujących, nazywających. W tym znaczeniu chcę mówić o twarzy bohatera i twarzy miasta. Z drugiej strony - jak również zauważa Hitchcock - twarz nie istnieje, dopóki nie zostanie oświetlona ${ }^{5}$. A oświetlana może być na różne sposoby. Twarz ta ma więc też w sobie potencjał do zmiany w zależności od tego, w jakim kontekście lub z jakiego punktu widzenia się jej przyglądamy. O takiej ambiwalencji twarzy pisze Marek Hendrykowski, zajmując się jej semiotyką:

Zmienność versus niezmienność. Zmieniając się przez całe życie, twarz stawia w każdym jego momencie pytanie o swoją tożsamość. Przeobrażając się nieustannie, jest jak mityczny statek Tezeusza. Paradoksalnie, odmienia się, przekształca, odnajduje coraz to inne okazjonalne maski i jednocześnie pozostaje sobą. Mimo zachodzących w niej zmian, jest przecież nadal rozpoznawalna ${ }^{6}$.

\section{KONSTRUKCJA I DEKONSTRUKCJA TWARZY}

Lokator jest filmem zrealizowanym na podstawie wydanej w 1913 roku książki Marie Belloc Lowndes. Reżyser lubił tę powieść i dokonał dość wiernej jej adaptacji ${ }^{7}$. Hitchcock opowiedział historię, w której z jednej strony widzimy efekt działania psychopatycznego mordercy, upatrującego

5 To stwierdzenie Hitchcocka cytowane jest w dokumentalnym filmie Hitchcock / Truffaut, reż. K. Jones, USA, 2015.

6 M. Hendrykowski, Semiotyka twarzy, Poznań 2017, s. 12.

7 Zob. np. P. McGilligan, op. cit., s. 104. 
sobie na ofiary młode kobiety o blond włosach. Morderca posługuje się pseudonimem „Avenger”. Swój podpis zostawia przy zwłokach zamordowanych kobiet, wpisując go w znak trójkąta. Drugą płaszczyznę historii stanowi trójkąt miłosny: Daisy - modelka, a zarazem potencjalna ofiara Avengera (jest młoda i ma jasne włosy), Joe - policjant, któremu zostanie powierzone dochodzenie w sprawie mordercy, oraz tajemniczy mężczyzna, który wynajmuje pokój u rodziców Daisy. Lokator z wzajemnością zauroczy się Daisy, ale jednocześnie wzbudzi niepokój rodziców dziewczyny swoim nietypowym zachowaniem. Również Joe zacznie podejrzewać, że lokator może być Avengerem, którego poszukuje. Po kolejnym morderstwie Joe aresztuje lokatora (znaleziona w czasie rewizji mapa z zaznaczonymi miejscami zabójstw wydaje się rozstrzygać o jego winie), temu jednak udaje się uciec. Dochodzi do pogoni, w której uczestniczą również mieszkańcy dzielnicy. W ostatniej chwili, tuż przed dokonaniem samosądu, lokatora ratują Daisy i Joe. Prawdziwy Avenger zostaje złapany na gorącym uczynku.

Film Lokator jest trzecim obrazem w dorobku Hitchcocka, pierwszym jednak - jak sam mówi - prawdziwym „Hitchcock Picture”. Stwierdzenie to implikuje dwie rzeczy. Jest to pierwszy film, który reżyser zrealizował zgodnie z własną koncepcją kina, jednak aby móc sobie na nią pozwolić, Hitchcock musiał zrozumieć i przyswoić - to druga rzecz - zasady funkcjonowania kina jako takiego. Te pierwsze przemyślenia dotyczące tworzenia filmu i sposobu funkcjonowania kinematografii przypadają na okres kina niemego. Hitchcock w pełni akceptuje zasady rządzące tą formą wypowiedzi filmowej, co więcej: upatruje w niej jądro filmowości, pewną niezmienną konstytucję, do której odwołuje się w całej swojej twórczości, również tej posługującej się dźwiękiem. Jak wyjaśnia w rozmowie z francuskim reżyserem:

Filmy nieme to najczystsza forma kina. Jedyna rzecz, której brakowało filmom niemym, to był oczywiście dźwięk, dźwięk naturalny. Ale ta jedyna niedoskonałość nie usprawiedliwia ogromu zmian, które przyniosło jego nadejście. Nie warto było porzucać całej techniki czystego kina?.

Zdaniem Hitchcocka, aby uniknąć formuły, którą on sam nazywa „fotografią mówiących ludzi”, dialogi powinno się stosować tylko wówczas, gdy

8 F. Truffaut, op. cit., s. 43.

9 Ibidem, s. 57. 
nie ma możliwości zastosowania „kinowego sposobu opowiadania historii: przez następstwo ujęć i scen"10. W przeciwnym wypadku twórca naraża się na utratę stylu filmowego, czyli tak naprawdę utratę tego, co decyduje o tym, że film jest sztuką, że posługuje się fantazją ${ }^{11}$. Reżyser wyjaśnia dalej:

Kiedy pisze się scenariusz, niezbędne jest wyraźne oddzielenie elementów dialogowych od elementów wizualnych; potem zaś zawsze, kiedy to tylko jest możliwe, trzeba wybierać elementy wizualne na korzyść dialogowych. Bez względu na to, do czego skłania rozwój fabuły, najważniejsze jest trzymanie widza w napięciu tak długo, jak się tylko da. W największym skrócie można by powiedzieć, że prostokąt ekranu musi być wypełniony emocją ${ }^{12}$.

Elementem, który spełnia z jednej strony warunek wizualności, a z drugiej emocjonalności, jest twarz. Zauważa to Hitchcock, gdy opowiada o wstępnej, piętnastominutowej sekwencji Lokatora. Podkreśla dwa ważne ujęcia: pierwsze otwierające film, w którym zastosował zbliżenie krzyczącej dziewczyny, drugie - gdy wiadomość o mordercy obiega wszystkie media, a kamera rejestruje emocje odbiorców. Dużo uwagi poświęcono w filmie twarzom ludzi, którzy wysłuchują relacji o mordercy w radiu. Brak dźwięku, czyli podstawowego kanału przekazu radiowego, powoduje, że twarz aktorów odgrywa podwójną rolę: po pierwsze, transmituje ten poziom komunikatu, który przekazywany jest przez spikera w warstwie dźwiękowej, a która przecież w filmie niemym przekazana być bezpośrednio nie może, a po drugie, na transmisję informacji nałożony jest przekaz emocjonalny związany z przeżyciem bohatera.

W przestrzeni teorii filmu Béla Balázs ${ }^{13}$ był jednym z pierwszych, którzy zastanawiając się nad znaczeniem filmu jako sztuki ${ }^{14}$, wiele uwagi

${ }^{10}$ Ibidem, s. 58.

${ }^{11}$ Ibidem.

12 Ibidem.

13 Myśl Balázsa, sformułowana blisko sto lat temu, współcześnie może wydać się już przebrzmiała, jednak, jak zauważają Thomas Elsaesser i Malte Hagener, w ostatnich latach można mówić o powrocie do jego teorii. Bezpośrednie odwołania widać na przykład w tekstach Gilles'a Deluze'a; zob. T. Elsaesser, M. Hegener, Teoria filmu: wprowadzenie przez zmysty, tłum. K. Wojnowski, Kraków 2015, s. 16 oraz 86-87.

14 Balázs zaliczany jest do tzw. formatywnej teorii filmu, która w przeciwieństwie do teorii realistycznej zajmuje się estetyką formy i rozpatruje kino 
poświęcił roli twarzy. Był właściwie pierwszym teoretykiem, jaki podjął się pełnej refleksji na ten temat ${ }^{15}$. Thomas Elsaesser i Malte Hagener zauważają, cytując fragment Visible Man or the Culture of Film ${ }^{16}$, jak duże znaczenie przywiązywał Balázs do zbliżenia i twarzy: „W prawdziwie artystycznym dziele napięcie między dwiema postaciami zawsze zostaje ukazane jako dialog między zbliżeniami wyrazów twarzy"17. Teoretyk zwracał uwagę na to, iż fizjonomia i mimika są najbardziej subiektywnymi formami wyrażania się człowieka. Zauważał, że mowa posługuje się wspólnymi regułami, które

w pierwszym rzędzie jako sztukę: „w myśl modernistycznych koncepcji estetyki starali się oni dowieść jedności każdej formy sztuki i jej niepowtarzalności” (A. Helman, J. Ostaszewski, Historia myśli filmowej. Podręcznik, Gdańsk 2007, s. 48). Do takiego podziału (zaproponowanego przez Siegfrieda Kracauera) odwołują się również autorzy Teorii filmu: wprowadzenie przez zmysły, dodatkowo zauważając, iż: „Zgodnie z tą klasyfikacją, Siergiej Eisenstein, Rudolf Arnheim, rosyjscy formaliści oraz amerykańscy neoformaliści byli orędownikami kina jako sztucznej konstrukcji (niezależnie od tego, czy zakorzeniają ja w klasycznej estetyce, polityce, czy kognitywizmie), a ich przeciwnicy skupiali się wokół osób Béli Balázsa, Siegfrieda Kracauera i André Bazina pod sztandarami »ontologicznego « realizmu" (T. Elsaesser, M. Hagener, op. cit., s. 11.). Warto podkreślić, że Elsaesser i Hagener włączają w jedną przestrzeń myślową Balázsa i Bazina, a ten ostatni był przecież niekwestionowanym mentorem François Truffauta. Aparat pojęciowy był oczywiście różny dla każdego z nich, niemiej łączył ich sposób patrzenia na film. Napięcie widoczne w rozumieniu dorobku Balázsa przez polskich badaczy i niemieckich historyków wynika z decyzji dotyczącej sposobu podejścia do tegoż, a w konsekwencji - wyraźniejszego naświetlenia różnych jego aspektów. Myślę, że doskonale łączy te dwa podejścia uwaga Aleksandra Jackiewicza, który zauważa, że podtytuł pierwszego dzieła Balázsa Człowiek widzialny brzmi: Kultura filmowa. Balázs, wychodząc od idei widzialności, postulował jej „dalszy rozwój właśnie ku sztuce widzenia, sztuce plastycznej, w przeciwieństwie do literatury - sztuce przeciwstawiającej, bez pośrednictwa pojęciowych środków wyrazu”; A. Jackiewicz, Béla Balázs, [w:] B. Balázs, Wybór pism, wybór i wstęp A. Jackiewicz, tłum. R. Porges, K. Jung, Warszawa 1957, s. 13.

15 Zob. T. Elsaesser, M. Hagener, op. cit., s. 83.

16 Oryginalny tytuł książki Balásza brzmiał w języku niemieckim: Der sichtbare Mensch, oder die Kultur des Films (Deutsch-Öster Verlag, Wien - Leipzig 1924); zob. B. Balázs, op. cit., s. 12.

${ }_{17}$ T. Elsaesser, M. Hagener, op. cit., s. 83. 
w dużym stopniu niweczą subiektywizm wyrażania: „[...] choć człowiek uczy się przeważnie mimiki - wyjaśniał dalej - to jednak nie podlega ona skodyfikowanym prawom. Ten najbardziej subiektywny środek wyrazu staje się obiektem dla zbliżenia"18.

Hitchcock decyduje się na zbliżenie twarzy, pokazując relacje między wzajemnie zafascynowanymi bohaterami czy lęk rodziców o życie córki. Idzie jednak o krok dalej i wykorzystując siłę napięcia, o którym pisze Balázs, włącza w nie samego widza. Tytułowy lokator, gdy w końcu decyduje się pocałować swoją wybrankę, portretowany jest en face, subiektywna kamera pokazuje jego twarz dokładnie tak, jak widzi ją kobieta. Chwila, gdy twarz Ivora Novello, wielkiej gwiazdy angielskiego teatru, pokazana jest w dużym zbliżeniu i w gotowości do pocałunku, musiała być niesamowitym przeżyciem dla jego wielbicielek. Przeciwnik Novello - w tego rodzaju dialogu z widzem - pokazywany jest w chwilach konsternacji czy wahania. Wymowna pod tym względem jest scena, gdy Joe zaczyna podejrzewać lokatora o dokonywanie zabójstw w Londynie. Dostrzega on na mokrej ziemi ślad po bucie lokatora. Kamera filmuje ów ślad i metodą przenikania pokazuje ułamki sytuacji, których Joe był świadkiem. Po cięciu montażowym kamera rejestruje reakcję bohatera. Widzowie obserwują rosnące w nim napięcie, a potem pewność co do zasadności podejrzeń. Patrzą prosto w twarz Joe. Hitchcock wykorzystuje w tych ujęciach proces, który Balázs nazywa identyfikacją i uznaje za specyficzne zjawisko filmowe, niespotykane w innych sztukach:

Siedząc w kinie - pisze teoretyk - czujemy, jak kamera filmowa porywa nasz wzrok, zmuszając nas do zajęcia się akcją filmu. [...] Bohaterowie filmu nie muszą opowiadać nam, co czują, bo przecież sami to widzimy. To zaś, co oni widzą, widzimy tak samo jak i oni. Nie jestem związany z miejscem, na którym siedzę w kinie, i nie stamtąd widzę Romea i Julię. Oczami Romea widzę Julię na balkonie i oczami Julii patrzę z balkonu na Romea. Moja osobowość utożsamia się z postaciami z filmu. Na wszystko patrzę z ich stanowiska, gdyż sam nie posiadam jakiegoś własnego odrębnego punktu widzenia. [...] Moje oczy znajdują się teraz w kamerze i utożsamiają się ze

18 B. Balázs, op. cit., s. 72. 
spojrzeniem bohatera filmu. On zaś patrzy moimi oczami. Jest to proces psychologiczny, który nazywamy identyfikacją ${ }^{19}$.

Elsaesser i Hagener przypominają jeszcze jedną istotną myśl Balázsa, cytując Widzialnego człowieka:

Odkrycie prasy drukarskiej doprowadziło do tego, że ludzka twarz stawała się nieczytelna. Ludzie mogli teraz wyczytać tak wiele z innych źródeł, że inne formy komunikacji traciły na znaczeniu. [...] Obecnie nasza kultura znowu obrała zasadniczo odmienny kierunek - tym razem dzięki filmowi. [...] Cała ludzkość jest teraz zajęta uczeniem się na nowo dawno zapomnianego języka gestów i wyrazów twarzy. Ten język to nie substytut słów, jak na przykład komunikacja migowa, ale wizualne następstwo ucieleśnienia ludzkiej duszy. Człowiek znowu stanie się widzialny ${ }^{20}$.

Andrzej Gwóźdź to ujęcie percepcji sztuki filmowej nazywa „antropologią niemoty"21, Elsaesser i Hagener zauważają dodatkowo, że wizualność kina niemego, podkreślana w Widzialnym człowieku, a nieodwołująca się do komunikacji językowej (mówienie i pisanie), „odnalazła związek z epoką katedr i wielką tradycją obrazów religijnych"22. Podobny związek odnajduje również Hitchcock, łącząc niesprawiedliwie oskarżonego lokatora z postacią Chrystusa ${ }^{23}$; pierwszy raz, gdy wyświetla na jego twarzy cień krzyża, rzucany przez ramy okienne. O drugim przypadku tak rozmawia $z$ Truffautem:

F.T.: Nie będzie chyba nadinterpretacji w stwierdzeniu, że w tej scenie z kratami chciał pan przywołać postać Chrystusa: kiedy Ivor Novello...

A.H.: ...kiedy tłum podnosi go, a on ma związane ręce. Oczywiście, że o tym myślałem ${ }^{24}$.

Hitchcock ma świadomość funkcjonowania twarzy w kinie niemym i doskonale potrafi skonstruować i wykorzystać wrażenie, jakie wywołuje

19 Ibidem, s. 63-64.

20 T. Elsaesser, M. Hagener, op. cit., 84-85.

21 A. Gwóźdź, Pochwała widzialności. Ze studiów nad niemiecka myśla filmowa do roku 1933, Katowice 1990, s. 130.

22 T. Elsaesser, M. Hagener, op. cit., s. 85.

${ }_{23}$ Zob. K. Loska, Hitchcock - autor wśród gatunków, Kraków 2002, s. 15.

${ }^{24}$ F. Truffaut, op. cit., 48. 
w widzu relacja z jej przedstawieniem na ekranie. Jednocześnie wychodzi poza postulaty i definicje sformułowane przez Balázsa i pokazuje, że twarz wcale nie jest tak doskonale jednoznacznym medium. Bliskie ujęcie kobiecej twarzy rozpoczynające film, obecność samego reżysera w tekście filmu, historia niewinnego człowieka oskarżonego o zbrodnię - wszystko to elementy, które bardzo często wymieniane są jako stałe motywy filmów Hitchcocka. Są to też motywy bezpośrednio bazujące na twarzy, od twarzy wychodzące. Wydaje mi się, że w Lokatorze te motywy, konstruowane, powoływane do istnienia przez wpisanie ich w przestrzeń kadru, z równą siłą ulegają dekonstrukcji, rozpadowi. Obraz twarzy krzyczącej z przerażenia dziewczyny, który wprowadza nas w historię, stanowi jednocześnie bardzo mocny akcent emocjonalny, na który widz właściwie nie jest przygotowany. Brak przygotowania nie oznacza braku czytelności, jak chce tego Balázs: „Jeżeli widzimy przed sobą twarz w zbliżeniu, to odkrywamy w niej każdy szczegół tak, jakbyśmy patrzyli na nią przez mikroskop" ${ }^{25}$. Z drugiej strony jest coś, co rozbija jednoznaczny, silny znak. Hitchcock, gdy opowiadał o tym ujęciu, tłumaczył: „Oto jak je sfotografowałem: wziąłem szklaną płytę, umieściłem głowę dziewczyny na jej tle, rozprostowałem jej włosy tak, żeby wypełniały cały kadr, później oświetliłem ją od spodu dla podkreślenia koloru blond"26. Zestawienie silnych emocji z rysunkową, komiksową niemal realizacją powoduje, że twarz rodzi się i w tym samym momencie się rozpada. To, co emocjonalne, wchodzi w grę z tym, co wizualne. Podobne napięcie - zaznaczenie istnienia i jego braku - pojawia się w sytuacji, w której w przestrzeni kadru pojawia się sam Hitchcock. Z tym że z mocą uwidacznia się ono dopiero z perspektywy czasu. Krzysztof Loska pisze:

Krytycy zwyczajowo podkreślają specyficzną funkcję krótkich scen z udziałem Alfreda Hitchcocka, zwracając przy tym uwagę na znaczenie podpisu autora, który na wzór średniowiecznych mistrzów malarskich sygnował $\mathrm{w}$ ten sposób swoje dzieła. Ale problem autorskiej sygnatury jest podwójnie złożony: po pierwsze, podpis powinien być powtarzalny, konwencjonalnym i rozpoznawalnym znakiem, podczas gdy - wbrew powszechnej opinii jest on we wczesnej twórczości brytyjskiego reżysera czymś wyjątkowym: spośród siedemnastu filmów zrealizowanych w latach 1925-1934 możemy

25 B. Balázs, op. cit., s. 75.

26 F. Truffaut, op. cit., s. 44. 
wskazać tylko dwa - Lokatora i Szantaż - w których Hitchcock zaznacza swoją obecność w świecie przedstawionym. Po drugie umieszczenie sygnatury w obrębie tekstu filmowego rodzi pewien niepokój związany z jednej strony z ujawnieniem sztuczności świata [...], z drugiej ze statusem podpisu ${ }^{27}$.

Dla współczesnego widza niejako naturalnym jest oczekiwanie zobaczenia twarzy Hitchcocka w jego filmie, gdy jednak spojrzeć na to oczekiwanie z perspektywy historycznej, to w kontekście tego konkretnego filmu nie ma ona podstaw. Widzowie w 1927 r. nie mieli przecieź świadomości, że oglądają na ekranie twarz reżysera. Co więcej, nawet gdy uświadomimy sobie, że Lokator jest pierwszym filmem, w którym Hitchcock się pojawia, to pozostaje niepewność, czyją twarz widzimy: bohatera filmu czy reżysera.

Decyzja o zaangażowaniu do tytułowej roli Novello wiązała się z pogodzeniem dwóch oblicz w ramach jednej postaci. Hitchcock sam przyznaje: „Wykonawca głównej roli, Ivor Novello, był wielką gwiazdą angielskiego teatru. To jeden $\mathrm{z}$ problemów, $\mathrm{z}$ którym musimy sobie radzić $\mathrm{w}$ ramach systemu gwiazd: zdarza się, że ostrość fabuły trzeba osłabić, bo gwiazda nie może grać łajdaka"28. Odette Aslan, tłumacząc, czym w XX wieku był system gwiazd, cytuje André Malraux:

Gwiazda [...] jest to osoba obdarzona pewnym minimum talentu dramatycznego, której twarz wyraża, symbolizuje, uosabia instynkt zbiorowy: Marlena Dietrich nie jest aktorką tak jak Sarah Bernhardt, stanowi mit jak Fryne [...]. Wielka aktorka jest kobietą zdolną wcielić się w dużą ilość niepodobnych do siebie ról, gwiazda jest kobietą zdolną spowodować powstanie dużej ilości zróżnicowanych scenariuszy ${ }^{29}$.

Reżyser musiał zmienić zakończenie w stosunku do pierwowzoru literackiego, chociaż jak sam twierdził: „[...] w tego rodzaju historii lepiej byłoby, żeby bohater odchodził gdzieś w nocy, a widz nigdy dowiadywał się dokąd. Nie można było jednak tak postąpić z bohaterem granym przez gwiazdę. Trzeba było wyraźnie powiedzieć, że jest niewinny" ${ }^{30}$. Hitchcock wyko-

27 K. Loska, op. cit., s. 14.

28 F. Truffaut, op. cit., s. 43.

29 O. Aslan, Aktor XX wieku. Ewolucja techniki. Zagadnienia etyki, tłum. M.O. Bieńka, Warszawa 1978, s. 194.

30 F. Truffaut, op. cit., s. 44. 
rzystał napięcie, jakie powstawało na styku filmowej fabuły prowadzonej w taki sposób, by można było tytułowego bohatera posądzić o zbrodnie, i elementów spoza tekstu filmu, czyli aury związanej z postacią Novello. Widz tworzył postać Avengera na podstawie informacji podsuwanych mu przez reżysera i jednocześnie ją rozbijał, odwołując się do doświadczenia odbiorczego.

Hitchcock wykorzystuje niebywały potencjał tkwiący w twarzy pojawiającej się w przestrzeni ekranu, co więcej - wykorzystuje siłę zbliżenia wyrazu twarzy, by w bezpośrednią grę włączyć swojego widza. Jednocześnie tworzy kontrapunkt tej sytuacji, w którym skonstruowana twarz ulega rozbiciu. Znamienne, że o podobnym doświadczeniu pisze Loska, gdy szuka sposobu na uchwycenie Hitchcocka-autora:

Poszukując charakterystycznych cech twórczości Hitchcocka, musimy zwrócić uwagę nie tylko na to, co tworzy system tekstualny, pozostaje z nim w zgodne, ale również na to, co go równocześnie podważa, co pozornie nieistotne, drugorzędne, niemieszczące się w ramach określonych konwencji, burząc tym samym pewien ład, system oczekiwań. Wszystko bowiem opiera się tu na napięciu miedzy porządkiem a chaosem, prawdą a fałszem, iluzją a realnością, swojskością a niesamowitością; na przeciwstawieniu, które nie zmierza do ustanowienia pewnego ładu, ale do przedstawienia świata pełnego niepewności i niebezpieczeństw, pozbawionego stałości i równowagi ${ }^{31}$.

Poszukiwanie tożsamości autora jest działaniem związanym z konstruowaniem i dekonstruowaniem, i dopiero w tym napięciu dokonuje się pełne przedstawienie.

\section{TWARZ Z MGEY}

Hitchcock dość liberalnie podchodził do problemu adaptacji. Truffaut zwraca uwagę na fakt, że w dorobku reżysera jest wiele adaptacji, jednak są to z reguły teksty należące do literatury popularnej, które reżyser Lokatora „przerabia po swojemu, aż staną się filmami Hitchcockowskimi” ${ }^{2}$. Na sugestię dotyczącą adaptacji Zbrodni i kary Fiodora Dostojewskiego Hitchcock odpowiada:

${ }^{31}$ K. Loska, op. cit., s. 10.

32 F. Truffaut, op. cit., s. 63. 
Tak, ale ja nigdy tego nie zrobię, bo Zbrodnia $i$ kara jest cudzym dziełem. Często zarzuca się filmowcom hollywoodzkim, że zniekształcają pierwowzór literacki. Nigdy nie chciałbym być oskarżony o coś takiego. Każdą książkę czytam raz. Kiedy podstawowa idea odpowiada mi - adaptuję ją, po czym natychmiast o niej zapominam i robię kino. Nie potrafiłbym panu opowiedzieć Ptaków Daphne du Maurier. Czytałem tę powieść raz, w pośpiechu ${ }^{33}$.

Nie chcę skupiać się na analizie wykazującej relacje między powieścią Marie Belloc Lowndes The Lodger a filmem Hitchcocka, ponieważ nie jest to przedmiotem mojej refleksji. Ponadto dla reżysera film jest odrębnym bytem, rządzącym się swoimi prawami i przemawiającym swoim językiem. Wymaga innego rozłożenia akcentów. Niemniej chciałabym chwilę zatrzymać się na dwóch różnicach, które wydają mi się istotne w namyśle nad znaczeniem twarzy w filmie Hitchcocka. Pierwszy element, na jaki warto zwrócić uwagę, to tytuł filmu i tytuł powieści, drugi - zakończenie uniewinniające tytułowego bohatera.

Pisarka zatytułowała swoją powieść The Lodger, Hitchcock swoją opowieść wzbogacił o podtytuł: A Story of the London Fog. Tak skonstruowany tytuł łączy historię lokatora $\mathrm{z}$ historią londyńskiej mgły, tłumaczy pierwszą historię drugą. Czym była londyńska mgła? Współcześnie trudno w tej metropolii zaobserwować zjawisko, jakie miał na myśli reżyser, od początku stanowi ona jednak o swoistości tego miasta.

Wspomina o niej już Tacyt w swoim opisie inwazji Cezara - pisze Peter Ackroyd w biografii Londynu - a zatem mgła prześladowała Londyn od najdawniejszych czasów. Początkowo powstawała naturalnym sposobem, ale potem miasto stopniowo uniezależniało się od przyrody i wytworzyło własną atmosferę. Już w roku 1257 Eleonora Prowansalska, żona Henryka III, skarżyła się na dym i zanieczyszczenie powietrza w Londynie, a w XVI wieku Elżbieta I była osobiście „wielce zatroskana i rozgniewana z powodu dymu węglowego". W epoce elżbietańskiej nad stolicą wisiał już całun dymu, a wnętrza zamożniejszych londyńskich domów były czarne od sadzy. Jeden ze współautorów Chronicles Holinsheda informował, że w drugiej połowie XVI wieku znacznie wzrosła liczba kominków i uważano, że dym w izbie

33 Ibidem, s. 63-64. 
zapobiega butwieniu drewna i chroni zdrowie. Można by pomyśleć, że miasto lubiło ciemność ${ }^{34}$.

W opowieści Ackroyda mgła jest elementem tożsamości miasta do tego stopnia, że wnika w jego fizyczną strukturę, nadając ścianom kamienic oliwkowozielony bądź brązowy kolor, odciskając w ten sposób na twardym kamieniu swój ślad. To „najbardziej nienaturalne z naturalnych zjawisk”35 wywołuje wrażenie odrealnienia, nadaje swój rytm rzeczywistości, spowalnia ją, stwarza charakter halucynacyjnej niejednoznaczności. Deformuje dźwięki, czyniąc je przytłumionymi. Mieszkańcy we mgle tracą tożsamość, „stają się dla siebie nieodróżnialni” 36 i jednocześnie sami nie są w stanie do końca pojąć zasad procesu, któremu ulegają. „Być może - tłumaczy Ackroyd - Londyn wymyka się wyobraźni po części jako miasto zanurzone w ciemności, która nie należy ani do dnia, ani do nocy. We mgle Londyn stał się miastem skrytości i tajemnic, szeptów i gasnących kroków"37. Mgła wnika również w przestrzeń kulturową miasta, stając się - zdaniem biografa - najważniejszym bohaterem dziewiętnastowiecznych powieści czy inspiracją dla malarzy. Ackroyd cytuje Claude’a Moneta, który do Londynu przyjechał na przełomie XIX i XX wieku: „W Londynie nade wszystko kocham mgłę. [...] To mgła nadaje temu miastu ten wspaniały układ cieni i barw. W jej tajemniczym płaszczu te ogromne, regularne kloce nabierają dostojeństwa" ${ }^{\prime 3}$.

Mgła ze swoją niejednoznacznością, zacieraniem granic i struktur, niweczeniem tożsamości, pochłanianiem jednoznaczności doskonale wniknęła w fakturę sennych aspektów filmu Hitchcocka. Właściwie każdy kontakt bohaterów z zewnętrznym światem, każde wyjście poza budynek to kontakt z mgłą. W filmie są cztery istotne sekwencje, które kamera rejestruje jako rozgrywające się w londyńskiej mgle: w przymglonej przestrzeni rozgrywają się obydwa morderstwa i randka lokatora z Daisy; ostatnia z „mgielnych sekwencji” to ta, którą rozpoczyna ucieczka lokatora tuż po aresztowaniu. Mgła unosi się nad Tamizą i ciałem zamordowanej dziewczyny, mgła kłębi się, gdy lokator po raz pierwszy staje w drzwiach domu rodziców Daisy, mgła

34 P. Ackroyd, Londyn. Biografia, tłum. T. Bieroń, Poznań 2011, s. 337.

35 Ibidem, s. 339.

36 Ibidem.

37 Ibidem.

38 Ibidem, s. 341. 
pochłania uciekającego przed policją lokatora. Mgła tłumi światła latarni nad Tamizą, przysłania budynek rewii, zalewa ulice. Struktura miasta zniknęła. Zniknęła jego specyfika, zniknęła jego twarz. Londyn jest tylko mgłą i aż mgłą. „A Story”, którym posługuje się reżyser w tytule, jest z jednej strony historią, opowieścią, ale przywołuje też pojęcie mitu czy legendy. Lokator to pierwszy film, który Hitchcock zrealizował po powrocie z Niemiec, na fali głębokiej fascynacji niemiecki ekspresjonizmem. Pierwsze Märchenfilme, stanowiące jeden $\mathrm{z}$ najbardziej charakterystycznych wypowiedzi filmowych ekspresjonizmu, powstawały w latach 1913-1918, druga fala - skromniejsza ilościowo, ale znacząca artystycznie - przypada na lata $20 .{ }^{39}$ Jest to również moment, w którym Hitchcock uważnie przygląda się twórczości niemieckich reżyserów ${ }^{40}$. Nie mogło umknąć jego uwadze coś, co polska badaczka definiuje w następujący sposób:

Preferowany przez kino ekspresjonistyczne typ fabuły zdaje się dodatkowo sprzyja pełnej realizacji zadania polegającego na tworzeniu w filmie świata innego niż potocznie poznawalny, lecz w pełni realnego. Wiele anegdot filmów ekspresjonistycznych aktualizuje stare baśnie czy mity, wyzwalając widza z codziennego świata oraz uwalniając go od logiki i motywacji „życiowej”41.

Tomasz Kłys tłumaczy, że niemieckie poszukiwania w obrębie fantastyki, legendy i baśniowości były między innymi sposobem na estetyczną nobilitację filmu. Wydaje się, że Hitchcock zwrócił uwagę na jeszcze inny aspekt tego zagadnienia: znalazł w nim wspólny kod, wspólny język z widzem. Joseph Campbell, szukając zasad funkcjonowania mitu we współczesnych tekstach kultury, zauważa:

39 T. Kłys, Film niemiecki w epoce wilhelmińskiej i weimarskiej, [w:] Historia kina, t. 1: Kino nieme, red. T. Lubelski, I. Sowińska, R. Syska, TAiWPN Universitas, Kraków 2010, s. 400-401. Należy nadmienić, że badacz pisze o dwóch rozumieniach ekspresjonizmu: szerszym i węższym. W tym drugim znaczeniu Märchenfilme, realizowany w latach 1913-1918, przypadałby na czas preekspresjonizmu; ibidem, s. 419.

40 Zob. P. McGilligan, op. cit., s. 86-88; P. Ackroyd, Alfred Hitchcock, tłum. J. Łoziński, Poznań 2015, s. 34-35.

${ }^{41}$ J. Kłyszcz, Obraz jako opowiadanie. O poetyce filmu niemieckiego lat dwudziestych, [w:] Niemiecki ekspresjonizm filmowy, red. A. Helman, A. Madej, Katowice, 1985, s. 136-137. 
Z braku ogólnie przyjętych mitologii każdy z nas ma swój prywatny, nierozpoznany, szczątkowy, ale posiadający tajemną moc, panteon snów. Ostatnie wcielenie Edypa, ciąg dalszy romansu Pięknej i Bestii stoją dziś na rogu Czterdziestej Drugiej Ulicy i Piątej Alei, czekając na zmianę sygnalizacji świetlnej².

Balázs, zastanawiając się nad znaczeniem twarzy i znaczeniem zbliżenia $\mathrm{w}$ filmie, pisze natomiast:

Gdy spostrzegamy oblicze przedmiotu, następuje antropomorfizacja, jak ma to miejsce w mitologii, która stwarza bogów na podobieństwo człowieka. Zbliżenia filmowe są twórczymi środkami tej właśnie wielkiej wizualnej antropomorfizacji ${ }^{43}$.

Wykorzystując naturalne powinowactwo filmu i snu ${ }^{44}$, własną fascynację tym powinowactwem ${ }^{45}$, zdolność filmu do przenoszenia w przestrzeń

${ }^{42}$ J. Campbell, Bohater o tysiacu twarzy, tłum. A. Jankowski, Poznań 1997, s. 20. Badacz tłumaczy przyczyny utraty zdolności do sięgania do tradycji mitologicznej w rozmowie z Billy Moyersem; zob. Potega mitu. Rozmowy Billa Moyersa z Josephem Bampbellem, oprac. B.S. Flowers, tłum. I. Kania, Kraków 1994, s. 20 i n. Campbell, przygotowując pod koniec lat 40. ubiegłego wieku Bohatera o tysiącu twarzy, sięga po rozstrzygnięcia Zygmunta Freuda. Kłyszcz również zwraca uwagę na myśl Freuda (obok filozofii Nietzschego, Bergsona, Junga), gdy szuka filozoficznych źródeł ekspresjonizmu (por. J. Kłyszcz, op. cit., s. 132), nazwisko Freuda wielokrotnie przewijało się wreszcie w wypowiedziach komentujących twórczość Hitchcocka w dokumencie Hitchcock/Truffaut.

43 B. Balász, op. cit., s. 72.

44 Alicja Helman, analizując sen w aspekcie filmu, pisze: „Porównanie filmu do snu, a przeżyć widza do doświadczeń śnienia jest jedną z najstarszych metafor, którymi posługuje się myśl filmowa dla opisu swojego przedmiotu. Inspiracji w tej mierze dostarczało nie tylko potoczne przeświadczenie znajdujące swój wyraz w takich sformułowaniach jak »fabryka snów (pod adresem Hollywood), »sen na jawie« (o samym filmie), »śnić z otwartymi oczami« (o widzu w kinie), lecz i praktyka filmowa. Od samych narodzin kina realizatorzy próbowali zarówno przedstawić sen na ekranie, jak i imitować specyficzny sposób przejawiania się snów (zdjęcia nakładane, nieostrość, zamglenia, ruch zwolniony, nieoczekiwane połączenia montażowe), ich swoistą logikę, nie znające granic bogactwo obrazowe"; A. Helman, Sen [hasło], [w:] Słownik pojęć filmowych, t. 7, red. eadem, Wrocław 1994, s. 89.

${ }^{45}$ Zob. F. Truffaut, op. cit., s. 150-151, 242-243. Na oniryzm filmów Hitchcocka zwracają również uwagę komentatorzy twórczości Hitchcocka w filmie dokumentalnym Hitchcock/Truffaut. 
mitu poprzez przyglądanie się z bliska „obliczu przedmiotu”, Hitchcock uruchamia maszynerię mitu, która działa na wielu poziomach. Z jednej strony opowiada o mieście, o Londynie, nie poprzez użycie dokumentalnej kamery i pokazanie architektury miasta, tylko przez pokazanie najbardziej charakterystycznego dla niego zjawiska. Tworzy paradoksalny mit miasta, który z jednej strony pokazuje jego oblicze, a z drugiej - zasłania jego tożsamość. Dalej, czyniąc mgłę bohaterem równym bohaterowi ludzkiemu, reżyser próbuje opowiedzieć o strachu przed nieznanym i śmiertelnym niebezpieczeństwem czającym się w mgielnych zaułkach. Można sobie wyobrazić, że na tym poziomie postrzegania filmu widzowie odwoływali się do własnych obaw i własnych lęków. Ackroyd w cytowanym już eseju pisze:

$\mathrm{Z}$ powodu mgły latarnie gazowe często włączano za dnia, a ich płomienie wyglądały jak punkty ognia pośród skłębionych miazmatów. Na wielu ulicach nie było jednak oświetlenia, toteż ciemna mgła stanowiła doskonałą osłonę dla złodziei, przemocy i gwałtów. W tym sensie mgła rzeczywiście była specjalnością Londynu, ponieważ intensyfikowała i uwypuklała mroczniejsze aspekty charakteru miasta ${ }^{46}$.

Nie bez znaczenia jest też tu historia, do której odwołuje się zarówno pierwowzór powieściowy, jaki i film: historia seryjnego mordercy Kuby Rozpruwacza, który od pierwszych miesięcy 1888 roku mordował prostytutki w londyńskiej dzielnicy Whitechapel. Do końca nie wiadomo, ile kobiet padło jego ofiarą. Złoczyńcy nigdy nie schwytano. W świadomości mieszkańców miasta i widzów filmu Hitchcocka pozostawał więc cały czas ukryty gdzieś w mgle londyńskich ulic.

Balázs pisze, że mitologia zbliżenia polega na jego stwórczej mocy. Moc tę zbliżenie uruchamia dzięki temu, że pozwala $z$ innej perspektywy spojrzeć na oblicze przedmiotu. Jakie nowe oblicze mgły pokazuje Hitchcock w filmie? Oprócz tego, że jednocześnie zasłania i odsłania twarz, tożsamość Londynu, mgła u Hitchcocka konstruuje bohatera. Stwarza go z całą mocą swej enigmatyczności i zwodniczości, z całym potencjałem zacierania granic. Hitchcock konstruuje historię londyńskiego mordercy i lokatora w taki sposób, że, po pierwsze, widz ani razu nie widzi twarzy zabójcy,

${ }^{46}$ P. Ackroyd, Londyn, op. cit., s. 339. 
a po drugie - przez większą część filmu nie mamy do końca pewności, czy przypadkiem lokator nie jest mordercą. Więcej, kamera zdaje się wybierać te fragmenty, które wskazywałyby, że właśnie to lokator jest mordercą, którego wszyscy się boją.

Przyjrzyjmy się bliżej dwóm pierwszym sekwencjom z mgłą w tle, w czasie których reżyser przeprowadza widza przez dwa morderstwa. Początek filmu, zbliżenie twarzy krzyczącej kobiety, kamera jednak skoncentrowana jest tylko na jej przerażeniu, widz nie wie, co lub kto jest jego źródłem. Kolejna scena: ciało kobiety leży nad brzegiem Tamizy, mgła wypełnia całą przestrzeń, rozmywa światła lamp. Kiedy starsza kobieta tłumaczy tłumowi zgromadzonemu przy budce z herbatą: „Tall he was - and his face all wrapped up", i jednocześnie widać dziennikarza, który przekazuje telefonicznie informację o zdarzeniu, widz ma pełne prawo konstatować: będziemy przyglądać się poszukiwaniu mordercy. Na styku tego naturalnego pragnienia widza (znaleźć winnego) oraz niejednoznaczności wynikającej z braku twarzy prawdziwego zabójcy rozpoczyna się metaforyczna, stwórcza praca Hitchcockowskiej mgły. Na relację kobiety reaguje niski i krępy żartowniś: zasłania sobie twarz kołnierzem płaszcza. Jego twarz odbija się, dając zamazany obraz. Kobieta gestem wskazuje na odbicie i zdaje się mówić: „To on!”. Mistyfikacja zostaje szybko wykryta, a żartowniś zbesztany. Jednak gra pozorów się rozpoczęła. Być może dlatego Hitchcock żałował, opowiadając Truffautowi o furgonetce gazeciarzy, że nie udało mu się ujęcia z furgonetką-twarzą do końca skonstruować. Gdyby powstała, byłaby ważnym znakiem fałszywej twarzy, podobnie jak odbicie niskiego mężczyzny, który w przerażonych oczach kobiety stał się wysoki, dokładnie tak jak morderca. Znamienne, że Hitchcock powróci do gestu zasłonięcia twarzy kołnierzem okrycia. Powtórzy go lokator, siedząc na ławce po ucieczce przed fałszywie go oskarżającą policją. Na poziomie fabularnym będzie chronił się przed zimnem, wybiegł przecież w marynarce, jednak jego zasłonięta twarz odwrócona będzie w stronę kamery. Jakby w oczekiwaniu na ostateczne rozstrzygnięcie widza: czy to jest twarz zabójcy?

Historia zabójstwa dokonanego w mgielnych oparach nad rzeką powoli opanowuje miasto. Hitchcock pokazuje twarze dziewczyn z rewii, czytających wstrząsającą relację i oglądających własne twarze i własne reakcje w lustrach. Dłuższą chwilę koncentruje się też na twarzach słuchaczy audycji radiowych. W wyobraźni odbiorców medialnej informacji rodzi się obraz 
zabójcy. Rodzi się również w wyobraźni widza. Najważniejsze wskazówki: wysoki z zakrytą twarzą. I dokładnie taka postać pojawia się w drzwiach domu Buntingów. Szalenie znaczące jest, że pojawia się na tle gęstej, kłębiącej się mgły, jakby z niej - niczym z magicznej maszyny zmian - wychodziła. Jedna z pierwszych czynności, jakich dokonuje lokator po wejściu do pokoju, który wynajmie, to zamknięcie okna. Jest to gest odcięcia się od zewnętrzności, czyli odcięcia się od mgły, bo to przecież ona jest dominującym zjawiskiem. Ale mgła już rozpędziła się w swoim procesie stwórczym. Młody gazeciarz w jej oparach krzyczy o kolejnym zabójstwie, a na twarzy lokatora pojawia się znak (cień) krzyża. On już został oskarżony. Jak Chrystus. To mgła stworzyła jego fałszywą twarz z lęku, który ze sobą niesie, z niepewności, z zacierania form. Jest jeszcze jeden istotny element w tym kreacyjnym działaniu mgły, który świadczy o tym, jak głęboko wchodzi ona w znaczeniową strukturę filmu. Powrócę jeszcze na chwilę do eseju Ackroyda:

W rzeczywistości gęste opary otulały Londyn jeszcze w latach dwudziestych i trzydziestych. W In Search of London (1951) H.V. Morton wspomina taką mgłę, która „ograniczała widoczność do jednego metra, zamienia każdą latarnię w odwrócone rozmyte $\mathrm{V}$ i nadaje każdemu spotkaniu pełen grozy charakter koszmaru sennego"s7.

Czym innym jak nie trójkątem jest odwrócone „V”? To przecież w znak trójkąta Avenger wpisuje swoje imię. To spostrzeżenie rodzi pytanie, czy antropomorfizacja mgły nie jest tak głęboka, że to mgła jest Avengerem. Tym bardziej że - niczym w Nosferatu - symfonii grozy (1922) Friedricha Wilhelma Murnaua - w filmie Hitchcocka to cień bez twarzy zabija.

Znak trójkąta pojawia się też w napisach ekranowych, zwłaszcza w chwilach zapowiadających pojawienie się Daisy czy wskazujących na upływ czasu. Hitchcock doskonale zdawał sobie sprawę z roli napisów w niemym filmie ${ }^{48}$. Z punktu widzenia historycznego i analitycznego tak pisze o tym Marek Hendrykowski:

47 Ibidem, s. 342.

48 Hitchcock zaczynał swoją przygodę z filmem od projektowania kart tytułowych. Według McGilligana prawdopodobne jest, iż w ciągu dwóch pierwszych lat pracy w studio Islington Hitchcock przygotował napisy do ośmiu filmów (P. McGilligan, op. cit., s. 70). Hitchcock tłumaczy Truffautowi, że napisy mogły 
Filmy tego okresu [późnoniemego - przyp. I.T.-J.] nie tylko nie są pozbawione substancji werbalnej, ale charakterystyczna jest dla nich rozległość znaczeniotwórczych związków pomiędzy słowami pojawiającymi się na ekranie a innymi elementami konstrukcji filmowej. Napisy ekranowe plasują się wewnątrz pola oddziaływania określonej struktury komunikatu filmowego i muszą zostać uznane za integralny współczynnik semantyczny, ponieważ uczestniczą w systemie znaczeń tej struktury ${ }^{49}$.

Strukturalnie napisy opatrzone graficznym znakiem trójkąta pojawiają się na tym samym poziomie, na jakim funkcjonuje tytuł. Jeżeli znak trójkąta miałby być graficznym przedstawieniem złudnej gry, jaką daje relacja światła lamp i mgły, to napisy międzyujęciowe z jednej strony cały czas przypominają o kłamstwie, jakim obarczona jest percepcja mglistej rzeczywistości. Z drugiej podejmują grę - poprzez powielenie, odbicie znaku z diegezy filmu - z rzeczywistością gotową obarczyć niewinnego człowieka winą za zbrodnie.

Tę niejednoznaczność mgielnej rzeczywistości, mającą zdolność stwarzania i niszczenia twarzy, potwierdza jeszcze dodatkowo sekwencja ucieczki lokatora tuż po aresztowaniu. Dopełnia się kreacyjny plan, wszystko wydaje się zamknięte, policja aresztowała lokatora, pozostaje tylko czekać na rozstrzygnięcie sądu. Wówczas bohater mówi do Daisy: „Meet me by the lamp”. Ucieka. Zakochani spotykają się przy znanej im ławce, w świetle lampy otoczonej mgłą. I ta lampa, rzucająca światło w kształcie odwróconej litery „V”, jest teraz świadkiem i tłem dla opowieści lokatora. Miał siostrę,

kompletnie zmienić koncepcję założoną w scenariuszu: „Przecież aktor udawał tylko, że mówi, a jego wypowiedź pojawiała się następnie na planszy. Można więc było przypisywać postaciom wypowiedzi, jakie się tylko chciało; dzięki temu procederowi udawało się czasem uratować kiepskie filmy. Jeśli dramat był źle sfilmowany, źle zagrany i stawał się w efekcie śmieszny, pisało się dialogi komediowe i film osiągał sukces, bo uważano go za satyrę" (F. Truffaut, op. cit., s. 31). Marek Hendrykowski, pisząc o obecności słowa w kinie niemym, podaje nazwisko Hitchcocka (obok D.W. Griffitha, Ch. Chaplina, B. Keatona, S. Eisensteina i R. Claira) jako przykład reżysera indywidualisty, który doskonale znał kunszt tworzenia napisu filmowego; M. Hendrykowski, Słowo w filmie. Historia, teoria, interpretacja, Warszawa 1982, s. 48.

${ }^{49}$ Ibidem, s. 49. 
która była pierwszą ofiarą Avengera. Przyrzekł matce, że znajdzie sprawcę. Pod domem Daisy znalazł się, śledząc mapę zabójstw i przewidując kolejny krok zabójcy. Jak się okazuje, miał rację. Drugie zabójstwo przedstawione widzom w historii ma miejsce tuż za rogiem... Jesteśmy świadkami konstruowania twarzy lokatora. Jednak czy może ona być prawdziwa ${ }^{50}$, skoro akt stwórczy dokonuje się w permanentnej obecności mgły, a bohater ciągle pozostaje bez imienia?

Ackroyd, podsumowując niemieckie doświadczenia Hitchcocka, pisze:

U Murnaua podpatrzył technikę ruchomej kamery, która może zmieniać pozycje jak każda postać, nauczył się także wielu innych rzeczy. Jeśli chcesz pokazać na ekranie dom czy katedrę, to nie musisz tworzyć kopii. Wystarczy pokazać murowaną kolumnę, wielkie drewniane drzwi albo nawet ich fragment, a wyobraźnia widzów dopowie resztę. „Liczy się nie to, co widzisz na planie - powtarzał Murnau - liczy się to, co widać na ekranie" ${ }^{\text {"51. }}$.

Hitchcock nie musiał pokazywać całego Londynu, nie musiał w ogóle pokazywać Londynu, Londyn zaistniał przez swój fragment, przez mgłę, która była jego charakterystycznym zjawiskiem. W ten sposób nie był i był. Tak reżyser skonstruował enigmatyczną twarz miasta, której pełnia dokonała się w wyobraźni widzów. Wykorzystując doświadczenie obcowania z mgłą u widza, a w szczególności potencjał niepewności i lęku, jaki ono rodzi, uruchomił mechanizm tworzenia obrazów niebezpieczeństwa oraz gotowość przypisania odpowiedzialności za zbrodnie nawet tak znanej twarzy jak twarz Ivora Novello. Tożsamość pozostaje w tym filmie cały czas w pewnej potencjonalności, oscylując między skrajnościami ${ }^{52}$.

$* * *$

Czas powstawania Lokatora był dla Hitchcocka okresem znacznego zainteresowania z jednej strony radziecką szkołą montażu, z drugiej - niemieckim

${ }^{50}$ Loska zwraca uwagę na dwuznaczność retrospekcji, chociażby dlatego, że reżyser nie rezygnuje z subiektywnej kamery odzwierciedlającej widzenie Avengera; K. Loska, op. cit., s. 13-14.

${ }^{51}$ P. Ackroyd, Alfred Hitchcock, op. cit., s. 35.

${ }^{52}$ Nawet gdy przyjrzeć się napisom początkowym, to żaden $\mathrm{z}$ bohaterów nie ma przypisanego sobie nazwiska. 
ekspresjonizmem. W tych fascynacjach szukałabym źródeł, które pomogły Hitchcockowi odkryć wielki potencjał tkwiący w twarzy. Potencjał, który wychodzi poza rozstrzygnięcia Balázsa. Reżyser potrafił zrelacjonować doświadczenie Kuleszowa ${ }^{53}: \mathrm{w}$ połowie lat 60 . sam poddał własne oblicze próbie wzorowanej na pomyśle radzieckiego twórcy. „Efekt Kuleszowa” dowodzi, jak wielkie znaczenie w odczytaniu i w jakimś sensie dopełnieniu się twarzy ma udział samych widzów oraz to, z czym twarz zostaje zestawiona. Ciekawe rozstrzygnięcia dotyczące twarzy w ujęciu niemieckiego ekspresjonizmu można znaleźć w tekście Jolanty Kłyszcz, która pisze:

Somnambuliczny sen Cezara [Gabinet doktora Caligari, reż. R. Wiene (1920) - I.T.-J.] zamyka winę w nieświadomości. Widzimy twarz, która nigdy nie wyraża uczucia w pełni jego odcieni, a czyni je grymasem. Twarz, która nigdy nie żyje, a oznacza, twarz tragiczną, bo obdartą z prawa bycia tylko twarzą - aż twarzą żyjącego człowieka. W filmie ekspresjonistycznym twarz nie należy do nikogo, tylko do obrazu. Jest, by stać się obrazem, jest, by znaczyć, jest, by oznaczać uczucia w ich wartościach. To bardzo mało: twarz ludzka straciła swą istotę - godność przynależenia do człowieka ${ }^{54}$.

W takim pojmowaniu twarzy widzi badaczka jedną z kluczowych cech świadczących, że o danym filmie można mówić jako o filmie ekspresjonistycznym. Hitchcock nie jest aż tak radykalny, by twarze swoich bohaterów ograniczać tylko do oznaczania i funkcjonowania w roli elementu kadru filmowego podporządkowanego całości kompozycji; pozwala im też żyć. Można rzec, iż w tym napięciu między życiem (byciem ludzką twarzą) a oznaczeniem (byciem twarzą z obrazu) dokonuje się istnienie i brak twarzy w filmie Hitchcocka

${ }^{53}$ Inna sprawa, że wersje samego eksperymentu są różne, ponieważ sam Kuleszow różnie je opisuje; J. Wojnicka, Kino Rosji carskiej i Związku Sowieckiego, [w:] Historia kina, op. cit., s. 511.

54 J. Kłyszcz, op. cit., s 141. 


\section{Bibliografia}

Peter Ackroyd, Alfred Hitchcock, tłum. J. Łoziński, Zysk i s-ka, Poznań 2015. Peter Ackroyd, Londyn. Biografia, tłum. T. Bieroń, Zysk i s-ka, Poznań 2011.

Odette Aslan, Aktor XX wieku. Ewolucja techniki. Zagadnienia etyki, tłum. M.O. Bieńka, PIW, Warszawa 1978.

Béla Balázs, Wybór pism, wybór i oprac. A. Jackiewicz, tłum. R. Porges, K. Jung, Filmowa Agencja Wydawnicza, Warszawa 1957.

Joseph Campbell, Bohater o tysiącu twarzy, tłum. A. Jankowski, Zysk i s-ka, Poznań 1997.

Joseph Campbell, Potega mitu. Rozmowy Billa Moyersa z Josephem Campbellem, tłum. I. Kania, Signum, Kraków 1994.

Thomas Elsaesser, Malte Hagener, Teoria filmu: wprowadzenie przez zmysły, tłum. K. Wojnowski, TAiWPN Universitas, Kraków 2015.

Andrzej Gwóźdź, Pochwała widzialności. Ze studiów nad niemiecka myśla filmowa do roku 1933, WUŚ, Katowice 1990.

Alicja Helman, Jacek Ostaszewski, Historia myśli filmowej. Podręcznik, Słowo/ obraz terytoria, Gdańsk 2007.

Marek Hendrykowski, Semiotyka twarzy, WN UAM, Poznań 2017.

Marek Hendrykowski, Słowo $w$ filmie. Historia, teoria, interpretacja, PWN, Warszawa 1982.

Tomasz Kłys, Film niemiecki w epoce wilhelmińskiej i weimarskiej, [w:] Historia kina, t. 1: Kino nieme, red. T. Lubelski, I. Sowińska, R. Syska, TAiWPN Universitas, Kraków 2010.

Lew Kuleszow, Sztuka filmowa. Moje doświadczenia, red. i wstęp W. Godzic, tłum. zbiorowe, TAiWPN Universitas, Kraków 1996.

Krzysztof Loska, Hitchcock - autor wśród gatunków, Rabid, Kraków 2002.

Patrick McGilligan, Alfred Hitchcock. Życie w ciemności i petnym świetle, tłum.

J. Matys, A. i A. Nermerowie, I. Stąpor, Wydawnictwo „Twój Styl”, Warszawa 2005.

Niemiecki ekspresjonizm filmowy, red. A. Helman, A. Madej, WUŚ, Katowice 1985. Słownik pojęć filmowych, t. 7, red. A. Helman, Wiedza o Kulturze, Wrocław 1994. François Truffaut, Hitchcock / Truffaut, współpraca H. Scott, tłum., oprac. i posłowie T. Lubelski, „Świat Literacki”, Izabelin 2005.

Joanna Wojnicka, Kino Rosji carskiej i Związku Sowieckiego, [w:] Historia kina, t. 1: Kino nieme, red. T. Lubelski, I. Sowińska, R. Syska, TAiWPN Universitas, Kraków 2010. 


\section{Filmografia}

The Lodger - A Story of the London Fog, reż. Alfred Hitchcock, Wlk. Brytania 1927. Hitchcock/Truffaut, reż. Kent Jones, USA 2015.

\section{Źródła ilustracji}

François Truffaut, Hitchcock / Truffaut, współpraca H. Scott, tłum., oprac. i posłowie T. Lubelski, „Świat Literacki”, Izabelin 2005, s. 45.

Kadr z filmu The Lodger - A Story of the London Fog, reż. Alfred Hitchcock, Wlk. Brytania 1927.

\section{The Face and (Its) Lack. About Alfred Hitchcock's The Lodger}

The article concentrates on the way in which face is presented in the first 'Hitchcock Picture' - The Lodger movie. In this text, face is understood as a set of elements that determine identity, but also have the potential for changes. Starting from the drawing of an unsuccessful shot from the movie and referring to its full title (The Lodger - A Story of the London Fog), the author focuses not only on face, but also on the role of fog in presenting the face of the city and constructing the face of the title character. Alfred Hitchcock's decisions concerning the manner of presenting face are analyzed in the context of Béla Balázs theory and German film expressionism.

Keywords: Béla Balázs, face, film expressionism, fog, Alfred Hitchcock, identity. 